\title{
Computer genomics research at the bioinformatics conference series in Novosibirsk
}

\author{
Yuriy L. Orlov ${ }^{1,2^{*}}$, Elvira R. Galieva ${ }^{2}$ and Alexander V. Melerzanov ${ }^{3}$ \\ From 11th International Multiconference "Bioinformatics of Genome Regulation and StructurelSystems Biology" - BGRSISB- \\ 2018 \\ Novosibirsk, Russia. 20-25 August 2018
}

In this issue we present original research articles and highlight the studies on computational genomics discussed at BGRS $\backslash S B$ (Bioinformatics of Genome Regulation and StructurelSystems Biology) multi-conference (http://conf.bionet.nsc.ru/bgrssb2018/en/). The meetings on bioinformatics and systems biology BGRS $\backslash S B$ in Novosibirsk have been held biannualy since 1998. The conference committee prepared series of special postconference journal issues at range of journals covering computational genomics and biomedicine applications since 2014 (https://bmcgenomics.biomedcentral.com/articles/supplements/volume-15-supplement-12). Recent special issues of BioMed Central journals after the conference include manuscripts on genomics, bioinformatics and genetics, and collated as BMC Genomics (https:// bmcgenomics.biomedcentral.com/articles/supplements/ volume-20-supplement-3) [1], BMC Medical Genomics [2], BMC Systems Biology [3], BMC Bioinformatics [4], $B M C$ Evolutionary Biology [5], BMC Genetics [6], BMC Medical Genetics [7], and BMC Plant Biology [8] Supplements this year.

The main idea of the research discussed at BGRS meetings might be formulated as regulation - regulation of gene expression at transcription level, regulation of protein functions at chromosome level, regulation of physiological function of cell, regulation of gene function at organism level [9]. System biology approaches for studying of cell function regulation could be described by the theory of gene networks - the science area

\footnotetext{
* Correspondence: orlov@d-health.institute

${ }^{1}$ Digital Health Institute, I.M. Sechenov First Moscow State Medical University of the Ministry of Health of the Russian Federation (Sechenov University), 119991 Moscow, Russia

${ }^{2}$ Novosibirsk State University, 630090 Novosibirsk, Russia

Full list of author information is available at the end of the article
}

presented at first BGRS-1998 [9, 10]. Previous BGRS conference 2016 had been presented at BMC Genomics (https://bmcgenomics.biomedcentral.com/articles/supplements/volume-17-supplement-14) [11] and BioMed Central journals as well [12-14]. Fast development of high-throughput sequencing technologies extended range of applications lead to creation of more complex dynamical models $[15,16]$ and enhancement of databases based on genome-wide studies [17].

To review bioinformatics meetings in Novosibirsk let us note «Belyaev Readings-2017» - memorial conference on genetics devoted to 100th anniversary of the birth of Academician Dmitri K. Belyaev (1917-1985), an outstanding scientist, evolutionist and geneticist (http:// conf.bionet.nsc.ru/belyaev100/en). The series of BioMed Central journals in 2017 highlighted bioinformatics research from the Belyaev memorial conference [18-23] accompanied by "Vavilov journal of genetics and breeding" special journal issue [24]. The BGRS \SB-2018 conference got highlights at Frontiers in Genetics thematic issue "Bioinformatics of Genome Regulation and Systems Biology" with the title resembling abbreviation of BGRS $\backslash S B$ conference name (https://www.frontiersin.org/ research-topics/8383/bioinformatics-of-genome-regulation-and-systems-biology).

Here we selected the articles on computational molecular biology and biomedicine applications discussed at BGRS-2018 multi-conference [25, 26]. Below is a summary of these papers and the article in $B M C$ Molecular and Cell Biology [27] and BMC Medical Genomics [28] parallel issues with relevant references and background work.

Evgeniya Omelina and co-authors [25] present here the study on optimization of PCR conditions for Massively Parallel Reporter Assay (MPRA). This approach 
enables high-throughput functional evaluation of various DNA regulatory elements and their mutant variants. The assays are based on construction of highly diverse plasmid libraries containing two variable fragments, a region of interest and a barcode separated by a constant spacer sequence. The authors identified PCR parameters that ensure synthesis of specific (non-chimeric) products from highly diverse MPRA plasmid libraries.

This application is accompanied by the original research paper by Gera Pavlova et al. [27] from the same science group describing Patronin gene function in mitosis at BMC Molecular and Cell Biology special issue. Patronin belongs to the conserved protein family CAMSAP (calmodulin-regulated spectrin-associated proteins), which members bind the polymerizing microtubule minus ends. The precise role of Patronin in mitotic spindle assembly is poorly understood. G.A. Pavlova and colleagues show that Patronin associates with different types of microtubule bundles within the Drosophila mitotic spindle, and that it is required for their stability.

Liudmila Smirnova and co-authors [26] used omics technologies to study proteomes in schizophrenia and bipolar disorder. Since diagnostics of mental disorders is based only on clinical symptoms, there is a necessity in development of additional methods of diagnostics. The search for blood based biomarkers is important for modern biomedicine. Comparison of proteome profiles of different patient groups revealed sets of proteins specific for schizophrenia and bipolar disorder.

Elena Ignatieva et al. [28] present exome-wide search and functional annotation of genes associated in patients with severe tick-borne encephalitis. The paper published is at separate BMC Medical Genomics issue "Selected articles from BGRS $\backslash$ SB-2018: medical genomics (part 2)". The authors identified set of candidate genes harboring rare, potentially pathogenic variants in exomes of patients with encephalitis and analyzed their function, protein-protein interactions. Whole-exome sequencing followed by systems biology approach enabled to identify eight candidate genes (MAP4, WDFY4, ACTRT2, KLHL25, MAP2K3, MBD1, OR10J1, and OR2T34) that can potentially determine predisposition to severe forms of tick-borne encephalitis.

To highlight genomics studies at presented at first BGRS-2018 special issue of BMC Genomics this year (https://bmcgenomics.biomedcentral.com/articles/supplements/volume-20-supplement-3) note the work by Wang and coauthors [29] discussing method for chromosome structure analysis based on integration of DNA sequences, ChIP-Seq and ChIA-PET data. The authors proposed the HidPET (Hierarchical and Dynamics Analysis of TF Cooperation with ChIA-PET and ChIPSeq Data) continuing work on 3D genome modeling presented first at BGRS-2014 conference [30].
A.A.Yurchenko et al. [31] at same BMC Genomics issue published work on animal genomics - high-density genotyping on sheep breeds. The authors performed a high-density genotyping and comprehensive scans for signatures of selection in the genomes from 15 local sheep, found candidate genes related to morphology, adaptation, and domestication as well as wool quality and related features.

D.Konina and colleagues [32] presented study LINC01420 - long noncoding RNA. It was shown that some lncRNAs have small open reading frames (smORFs) that produce the functional microproteins. Konina and co-authors investi analyzed gated widely expressed IncRNA LINC01420, the function of which was not described at the time of the beginning of the study. D'Lima et al. [33] found smORF in the first exon of the LINC01420 gene. This smORF produces functional microprotein called non-annotated P-body dissociating polypeptide (NoBody) [34]. Konina and colleagues provided new facts about LINC01420 and its function.

L.A.Fedoseeva et al. [35] discussed the differences in brain stem transcriptional profiling in rat models of hypertension. The authors revealed set of differentially expressed genes and discussed their association with hypertension and blood pressure regulation, considered association with central nervous system diseases. This study continues research on transcriptome profiling on selection rats models [36] at the Institute of Cytology and Genetics SB RAS including published in BMC Genomics special issues in 2016 [37].

Concluding genomics research review at BGRS $\backslash S B-$ 2018 conference note article by N.V.Ivanisenko et al. [38], work in plant genomics by I.V.Rozanova and coauthors [39].

Another important bioinformatics meeting in Novosibirsk - International Young Scientists School "Systems Biology and Bioinformatics" (SBB) (http://conf.bionet.nsc. ru/bgrssb2018/en/school/), an educational School on systems biology has own history and publications record in BMC thematic issues [40-42], see also BMC Genomics Supplement (https://bmcgenomics.biomedcentral.com/articles/supplements/volume-16-supplement-13). Note SBB2019 event to be held in Novosibirsk in June 2019 (http:// conf.bionet.nsc.ru/sbb2019/en/) in parallel to Plantgen2019 conference. These meetings continue traditions of bioinformatics conference series in Novosibirsk organized by the Institute of Cytology and Genetics SB RAS and Novosibirsk State University. The great traditions of bioinformatics education summer schools to be continued this year in Russia by the event organized by Moscow Institute of Physics and Technology (MPTI) and Bioinformatics Institute in St. Petersburg (https://bioinf.me/ education/summer/2019). 
Concluding this short review of bioinformatics research post-conference thematic issues on genomics we invite our readers worldwide to participate next educational bioinformatics meetings - Systems Biology and Bioinformatics Young Scientists School SBB-2019 in Novosibirsk, Forum on Digital Medicine at Sechenov University and Bioinformatics School in Moscow in 2019. The most significant materials discussed at these meetings will be presented at new BMC Genomics Supplement in 2019. Next BGRS\SB-2020 multiconference is scheduled for summer 2020 in Novosibirsk, Russia.

\section{Acknowledgements}

We are grateful to Professors A.V.Baranova, T.V.Tatarinova, N.A. Kolchanov, A.V.Kochetov, R. Hofestädt for organization of the multi-conference and providing platform for international bioinformatics research, and to Institute of Cytology and Genetics SB RAS and Novosibirsk State University for hosting the conferences. YLO and ERG were supported by RSF (grant 19-15-00219). Round table on education in bioinformatics in Novosibirsk was supported by the project "Investigation, analysis and complex independent expertize of projects of the National technological initiatives, including the accompanying of projects of "road map" "NeuroNet"' (state assignment 28.12487.2018/12.1 of the Ministry of Higher Education and Science of the Russian Federation). The guest editors of the special issue are grateful to the conference committee members and reviewers who helped in the articles editing and issue preparation.

\section{About this supplement}

This article has been published as part of BMC Genomics Volume 20 Supplement 7, 2019: Selected articles from BGRSISB-2018: genomics (part 2). The full contents of the supplement are available online at https://bmcgenomics.biomedcentral. com/articles/supplements/volume-20-supplement-7.

\section{Authors' contributions}

YLO is guest editor of the BGRS-2018 special post-conference issues; ERG and AVM are conference participants and organizers of associated bioinformatics educational events. All the authors read, revised and approved the final manuscript.

\section{Funding}

This article did not receive sponsorship for publication.

\section{Availability of data and materials}

Not applicable.

\section{Ethics approval and consent to participate}

Not applicable.

\section{Consent for publication}

Not applicable.

\section{Competing interests}

The authors declare that they have no competing interests.

\section{Author details}

'Digital Health Institute, I.M. Sechenov First Moscow State Medical University of the Ministry of Health of the Russian Federation (Sechenov University), 119991 Moscow, Russia. ${ }^{2}$ Novosibirsk State University, 630090 Novosibirsk, Russia. ${ }^{3}$ Moscow Institute of Physics and Technology (MIPT), 141700, Dolgoprudny, Moscow Region, Russia.

\section{Published: 11 July 2019}

\section{References}

1. Orlov YL, Kochetov AV, Li G, Kolchanov NA. Genomics research at Bioinformatics of Genome Regulation and StructurelSystems Biology (BGRSISB) conferences in Novosibirsk. BMC Genomics. 2019;20(Suppl 3):322.
2. Baranova AV, Klimontov W, Letyagin AY, Orlov YL. Medical genomics research at BGRS-2018. BMC Med Genomics. 2019;12(Suppl 2):36.

3. Orlov YL, Hofestädt R, Baranova AV. Systems biology research at BGRS-2018. BMC Syst Biol. 2019;13(Suppl 1):21.

4. Tatarinova TV, Chen M, Orlov YL. Bioinformatics research at BGRS-2018. BMC Bioinformatics. 2019;20(Suppl 1):33.

5. Orlov YL, Baranova AV, Kolchanov NA, Moroz LL. Evolutionary biology and biodiversity research at BGRS-2018. BMC Evol Biol. 2019;19(Suppl 1):43.

6. Orlov YL, Tatarinova TV, Kochetov AV. Computational models in genetics at BGRS-2018. BMC Genet. 2019;20(Suppl 1):28.

7. Baranova AV, Skoblov MY, Voropaeva EN, Shanmughavel P, Orlov YL. Medical genetics studies at BGRS conference series. BMC Med Genet. 2019; 20(Suppl 1):50.

8. Orlov YL, Salina EA, Eslami G, Kochetov AV. Plant biology research at BGRS2018.BMC Plant Biol. 2019;19(Suppl 1):56.

9. Heinemeyer T, Wingender E, Reuter I, Hermjakob H, Kel AE, Kel OV, Ignatieva EV, Ananko EA, Podkolodnaya OA, Kolpakov FA, Podkolodny NL, Kolchanov NA. Databases on transcriptional regulation: TRANSFAC, TRRD and COMPEL. Nucleic Acids Res. 1998;26(1):362-7.

10. Kolpakov FA, Ananko EA, Kolesov GB, Kolchanov NA. GeneNet: a gene network database and its automated visualization. Bioinformatics. 1998:14(6): $529-37$.

11. Orlov YL, Baranova AV, Hofestadt R, Kolchanov NA. Computational genomics at BGRSISB-2016: introductory note. BMC Genomics. 2016; 17(Suppl 14):996.

12. Orlov YL, Baranova AV, Markel AL. Computational models in genetics at BGRSISB-2016: introductory note. BMC Genet. 2016;17(Suppl 3):155.

13. Baranova AV, Orlov YL. Evolutionary biology at BGRSISB-2016. BMC Evol Biol. 2017;17(Suppl 1):21.

14. Orlov YL, Baranova AV, Salina EA. Computational plant bioscience at BGRSISB-2016. Introductory note. BMC Plant Biol. 2016;16(Suppl 3):243.

15. Likhoshvai VA, Khlebodarova TM, Bazhan SI, Gainova IA, Chereshnev VA, Bocharov GA. Mathematical model of the tat-rev regulation of HIV-1 replication in an activated cell predicts the existence of oscillatory dynamics in the synthesis of viral components. BMC Genomics. 2014;15(Suppl 12):S1.

16. Khlebodarova TM, Ree NA, Likhoshvai VA. On the control mechanisms of the nitrite level in Escherichia coli cells: the mathematical model. BMC Microbiol. 2016:16(Suppl 1):7.

17. Kulakovskiy IV, Vorontsov IE, Yevshin IS, Sharipov RN, Fedorova AD, Rumynskiy El, Medvedeva YA, Magana-Mora A, Bajic VB, Papatsenko DA, Kolpakov FA, Makeev VJ. HOCOMOCO: towards a complete collection of transcription factor binding models for human and mouse via large-scale ChIP-Seq analysis. Nucleic Acids Res. 2018;46(D1):D252-9.

18. Orlov YL, Baranova AV, Hofestädt R, Kolchanov NA. Genomics at Belyaev conference - 2017. BMC Genomics. 2018;19(Suppl 3):79.

19. Orlov YL, Baranova AV, Herbeck YE. Evolutionary biology at Belyaev conference - 2017. BMC Evol Biol. 2017;17(Suppl 2):260.

20. Orlov YL, Moroz LL, Baranova AV. Neuroscience researches at Belyaev conference-2017. BMC Neurosci. 2018:19(Suppl 1):14.

21. Orlov YL, Baranova AV, Tatarinova TV, Kolchanov NA. Genetics at Belyaev conference - 2017: introductory note. BMC Genet. 2017;18(Suppl 1):116.

22. Orlov YL, Baranova AV, Chen M, Salina EA. Plant biology at Belyaev conference - 2017. BMC Plant Biol. 2017;17(Suppl 2):257.

23. Orlov $Y L$, Fernandez-Masso JR, Chen M, Baranova AV. Medical genomics at Belyaev conference - 2017. BMC Med Genomics. 2018;11(Suppl 1):11.

24. Shumny VK. To the centenary of the birth of outstanding evolutionist Dmitri Konstantinovich Belyaev. Vavilovskii Zhurnal Genetiki i Selektsii = Vavilov. J Genet Breed. 2017;21(4):387-91. https://doi.org/10.18699/NJ17.256 (In Russian).

25. Omelina ES, Ivankin AV, Letiagina AE, Pindyurin AV. Optimized PCR conditions minimizing the formation of chimeric DNA molecules from MPRA plasmid libraries. BMC Genomics. 2019;20(Suppl 7). https://doi.org/10. 1186/s12864-019-5847-2

26. Smirnova L, Seregin A, Boksha I, Dmitrieva E, Simutkin G, Kornetova E, Savushkina O, Letova A, Bokhan N, Zgoda V, Ivanova S. The difference in serum proteomes in schizophrenia and bipolar disorder. BMC Genomics. 2019;20(Suppl 7). DOI:10.1186/s12864-019-5848-1

27. Pavlova GA, Razuvaeva AV, Popova JV, Andreyeva EN, Yarinich LA, Lebedev MO, Pellacani C, Bonaccorsi S, Somma MP, Gatti M, Pindyurin AV. The role of Patronin in Drosophila mitosis. BMC Molecular and Cell Biology. 2019; 20(Suppl 1):7. 
28. Ignatieva EV, Yurchenko AA, Voevoda MI, Yudin NS. Exome-wide search and functional annotation of genes associated in patients with severe tick-borne encephalitis in a Russian population. BMC Med Genomics. 2019;12(Suppl 3): 61.

29. Wang R, Wang Y, Zhang X, Zhang Y, Du X, Fang Y, Li G. Hierarchical cooperation of transcription factors from integration analysis of DNA sequences and ChIP-Seq and ChIA-PET data. BMC Genomics. 2019; 20(Suppl 3):296.

30. Li G, Cai L, Chang H, Hong P, Zhou Q, Kulakova EV, Kolchanov NA, Ruan Y. Chromatin interaction analysis with paired-end tag (ChIA-PET) sequencing technology and application. BMC Genomics. 2014;15(Suppl 12:S11.

31. Yurchenko AA, Deniskova TE, Yudin NS, Dotsev AV, Khamiruev TN, Selionova MI, Egorov SV, Reyer H, Wimmers K, Brem G, Zinovieva NA, Larkin DM. Highdensity genotyping reveals signatures of selection related to acclimation and economically important traits in 15 local sheep breeds from Russia. BMC Genomics. 2019;20(Suppl 3):294.

32. Konina DO, Filatova AY, Skoblov MY. LINC01420 RNA structure and influence on cell physiology. BMC Genomics. 2019;20(Suppl 3):298.

33. D'Lima NG, Ma J, Winkler L, Chu Q, Loh KH, Corpuz EO, et al. A human microprotein that interacts with the mRNA decapping complex. Nat Chem Biol. 2016;13(2):174-80

34. Sousa ME, Farkas MH. Micropeptide. PLoS Genet. 2018;14(12):e1007764.

35. Fedoseeva LA, Klimov LO, Ershov NI, Efimov VM, Markel AL, Orlov YL, Redina OE. The differences in brain stem transcriptional profiling in hypertensive ISIAH and normotensive WAG rats. BMC Genomics. 2019;20(Suppl 3):297.

36. Kozhevnikova OS, Korbolina EE, Stefanova NA, Muraleva NA, Orlov YL, Kolosova NG. Association of AMD-like retinopathy development with an Alzheimer's disease metabolic pathway in OXYS rats. Biogerontology. 2013; 14(6):753-62.

37. Fedoseeva LA, Klimov LO, Ershov NI, Alexandrovich $\mathrm{Y}$, Efimov VM, Markel AL, Redina OE. Molecular determinants of the adrenal gland functioning related to stress-sensitive hypertension in ISIAH rats. BMC Genomics. 2016; 17(Suppl 14):989.

38. Ivanisenko N, Buchbinder JH, Espe J, Richter M, Bollmann M, Hillert L, Ivanisenko V, Lavrik IN. Delineating the role of c-FLIP/NEMO interaction in the CD95 network via rational design of molecular probes. BMC Genomics. 2019;20(Suppl 3):293.

39. Rozanova IV, Lashina NM, Mustafin ZS, Gorobets SA, Efimov VM, Afanasenko OS, Khlestkina EK. SNPs associated with barley resistance to novel isolates of Pyrenophora teres f. teres. BMC Genomics. 2019;20(Suppl 3):292.

40. Kolchanov NA, Orlov YL. Introductory note for BGRS-2012 special issue. J Bioinform Comput Biol. 2013;11(1):1302001.

41. Baranova AV, Orlov YL. The papers presented at 7th young scientists school "systems biology and bioinformatics" (SBB'15): introductory note. BMC Genet. 2016;17(Suppl 1):20.

42. Orlov YL, Hofestädt R, Tatarinova TV. Bioinformatics research at BGRS \SB2018. J Bioinform Comput Biol. 2019;17(1):1902001

\section{Publisher's Note}

Springer Nature remains neutral with regard to jurisdictional claims in published maps and institutional affiliations.

Ready to submit your research? Choose BMC and benefit from:

- fast, convenient online submission

- thorough peer review by experienced researchers in your field

- rapid publication on acceptance

- support for research data, including large and complex data types

- gold Open Access which fosters wider collaboration and increased citations

- maximum visibility for your research: over $100 \mathrm{M}$ website views per year

At $\mathrm{BMC}$, research is always in progress.

Learn more biomedcentral.com/submissions 